\title{
A Magyar Királyi Honvédség ejtőernyős csapatnemének története 1937 és 1945 között
}

A magyar katonai ejtőernyőzés előzményei az I. világháborúig nyúlnak vissza, amikor a repülőhajózók és a léghajók megfigyelő személyzete számára, személyi mentőeszközként elsőként rendszeresítettek ejtőernyőt. ${ }^{1}$ Az I. világháború alatt végrehajtott 177 magyar ejtőernyős ugrás ${ }^{2}$ végrehajtói között tartjuk számon Poppe Kornél cs. és kir. századost, aki 1918. január 16-án hajtott végre ejtőernyős ugrást kötött ballonból ${ }^{3}$, Boksay Antal főhadnagyot, aki 1918. március 23-án ugrott a perginei repülőtéren, és Hefty Frigyes repülő törzsőrmestert, aki 1918. augusztus 23-án, a piavei fronton ugrott ki sérült repülőgépéből. 4

$A z$ I. világháborút követően a katonai teoretikusok olyan új megoldásokat kerestek az állóháború jelentette kihívások

\section{1. ábra. A kísérleti ejtőernyős keret tagjai 1938-ban. Középen} vitéz Bertalan Árpád százados

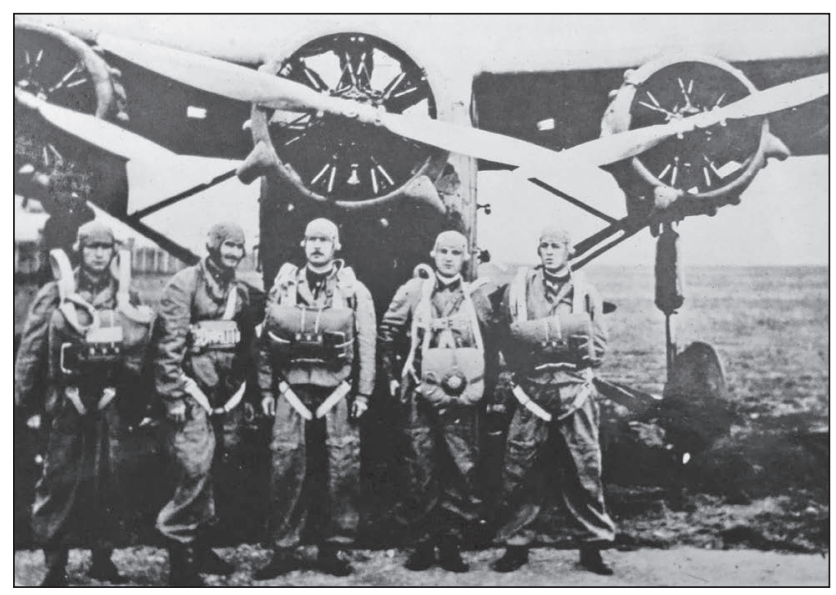

leküzdésére, amelyek mindegyike az I. világháború második felében kialakult rohamharcászat és a technológiai újítások, mint például a harckocsik, vagy épp az ejtőernyő ötvözésén alapultak. Így nem meglepő, hogy az 1930-as évek második felétől a magyar katonai szaksajtó is élénken foglalkozott a kérdéssel, zömében a külföldi tapasztalatok alapján.

A korszakban megjelenő szakcikkek konklúziója általánosságban az volt, hogy az ejtőernyős kirakás hadászati értelemben nem kecsegtet nagyobb előnyökkel, esetlegesen harcászati jelentősége lehet. ${ }^{5}$ Ezeket a kétkedő hangokat a szovjet-orosz ejtőernyős sikerek sem hallgattatták el, amelyek egyébként 1934 és 1935 során az egész világ figyelmét felkeltették. ${ }^{6}$

A magyar katonai ejtőernyőzés számára a lendületet a szovjet-orosz kísérletek mellett a német ejtőernyős fegyvernem kialakulása jelentette, hiszen 1936 és 1937 folyamán mind a légierő (a Luftwaffe), mind pedig a szárazföldi haderő (a Heer) létrehozta a maga ejtőernyős alakulatait, összhangban a német összfegyvernemi támadó stratégia, a villámháború (Blitzkrieg - gyors lefolyású, mozgáscentrikus-manőverező elvek figyelembevételével vívott hadviselés - Szerk.) alapelveivel.

Az első, ejtőernyős kiképzést is magában foglaló program, a Testnevelési Szaktanfolyam, 1938. május 3-án alakult meg Szentendrén, a VKF V. osztálya, az elvi és katonapolitikai osztály, később a VKF 2. osztály, azaz a hírszerzés és kémelhárítás irányítása alatt. ${ }^{8} \mathrm{~A}$ tanfolyamon zömmel a trianoni békediktátum által elcsatolt területekről származó, a helyi viszonyokat ismerő, románul, csehül, szlovákul jól beszélő, érettségizett katonák vettek részt. ${ }^{9}$ A szaktanfolyam elindításának célja dr. Csongor Győző, egykori résztvevő szerint:

„(...) hogy a magyar hadsereg tartalékos állományából különleges képesitésü, magasabb szintü katonai ismeretek
ÖSSZEFOGLALÁS: A II. világháború során a Magyar Királyi Honvédségen belül, külföldi sikerek nyomán jött létre az első kísérleti ejtőernyős keret Szombathelyen. A saját tapasztalatokra épító alakulat előbb század-, zászlóalj-, majd a háború végén ezredméretben múködött Pápán. Az alakulat részt vett a területgyarapodás során az erdélyi 1940-es és az 1941-es délvidék bevonulásban is, az utóbbi során ejtőernyős harci ugrást végrehajtva. Ezt követően 1944-ben az ejtőernyősök a magyarországi harcokban tűzoltóalakulatként, könnyügyalogosként vettek részt. A klasszikus ejtőernyős lövészképesség mellett elit könnyügyalogságként és különleges múveleti alegységként is bevethető alakulat önkéntesei sokrétủ kiképzésüknek köszönhetően kiemelkedő teljesítményt nyújtottak a harctéren.

KULCSSZAVAK: ejtőernyős, Magyar Királyi Honvédség, II. világháború, vitéz Bertalan Árpád, Szent László Hadosztály, különleges erők
ABSTRACT: During the Second World War, inspired by foreign successes an experimental parachute unit has been established in the Royal Hungarian Army at Szombathely, Hungary. The unit, depending on its own experiences has became a company, then a battalion, then a regiment-sized element of the army, located at Pápa, Hungary. The unit has participated in the retake of parts of Transylvania in 1940 and in the retake of the Southern Parts in 1941, conducting a combat parachute jump. During 1944 the Hungarian paratroopers have been deployed as a "firefighter unit", fighting as light infantry. In addition to its airborne capability as parachute infantry the unit has been able to act as elite light infantry, and also as a Special Operations capable unit due to its specialized training. The volunteers of this unit, thanks to their versatile training have performed outstandingly on the battlefields.

KEY WORDS: paratrooper, Royal Hungarian Army, Second World War, Árpád Bertalan, Szent László Division, Special Forces

Különleges műveleti kutató, katonai hagyományőrző, az ELTE BTK Hadtörténelmi Műhelyének társszervezője, davidkiss0112@gmail.com, ORCID: 0000-0002-8680-4178 
birtokában (...) különböző fegyvernemekbeni (sic!) jártasság mellett különféle katonai teljesítmények elérésére alkalmas egyéneket nyerjenek. Magyarán szólva: a jelöltek a képzés eredményeként földön, égen (levegöben) egyaránt használhatók legyenek."10

A szaktanfolyamon résztvevő, összesen 92 fő karpaszományos önkéntes a vízi kiképzés, hosszú kerékpártúrák és a lövészet cseh és román pisztolyokkal, ${ }^{11}$ valamint a rádió adó-vevők használata mellett megismerte az ejtőernyős ugrás gyakorlati alapjait is. ${ }^{12} \mathrm{~A}$ kiképzés kezdetlegességére jellemző, hogy megfelelő eszközpark hiányában a diverzáns-jelöltek egyszerűen 5-7 méter magas szalmakazlakról ugráltak a földre. Az ugrókiképzést Czékus Ferenc repülő százados irányította. A katonák általában három ugrást hajtottak végre Salvator típusú olasz és Irvin típusú angolamerikai ejtőernyőkkel bekötött, és kézi kioldású nyitási módszerrel egyaránt. ${ }^{13}$

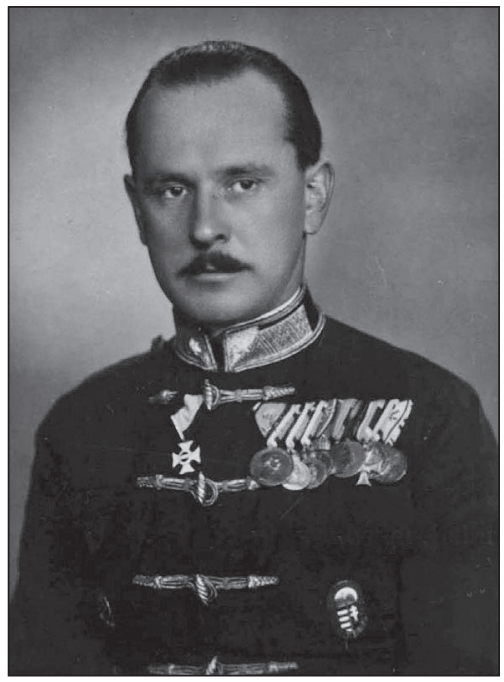

\section{2. ábra. Vitéz}

Bertalan Árpád örnagy, az ejtőernyős zászlóalj első parancsnoka

Ezt a tanfolyamot tekintette meg 1938. szeptember 12-én vitéz Bertalan Árpád árkász százados és hat fiatal hadnagy, akik később hasznosították az itt látottakat. Így bár a Testnevelési Szaktanfolyamot 1938. augusztus 31-én feloszlatták, az ejtőernyőzéssel kapcsolatosan kialakult gyakorlati tapasztalatokat egy új alakulat hasznosította tovább. ${ }^{14}$

Az első deklaráltan ejtőernyős magyar katonai alakulat 1938. szeptember 11-én alakult meg Szombathelyen, hét tiszttel. Az Ejtőernyős Kísérleti Keret néven ismertté vált

\section{3. ábra. A Magyar Királyi Honvédség ejtőernyőskatonái a} pápai repülőtéren, a kiképzések közti pihenőben

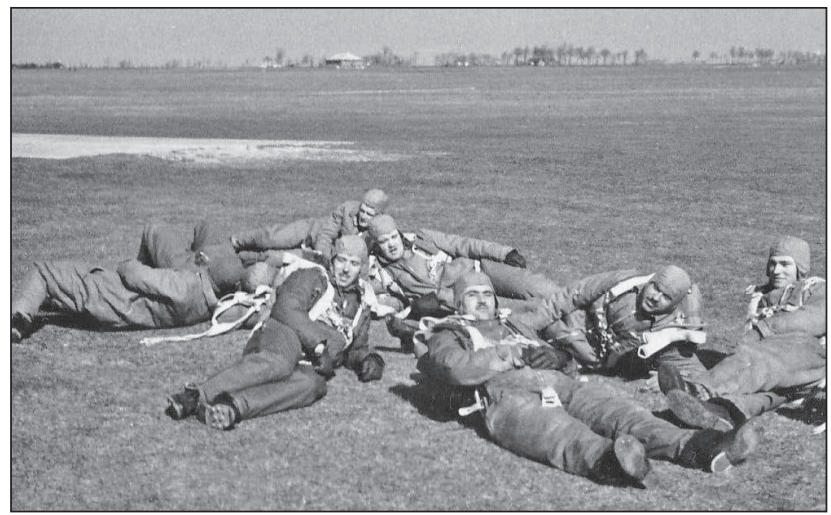

csoport feladata a Testnevelési Szaktanfolyam által megkezdett út folytatása, a magyar katonai ejtőernyőzés elméleti és gyakorlati alapjainak lefektetése volt. ${ }^{15}$

Az ekkor 40 esztendős, a Katonai Mária Terézia Rend Lovagkeresztjével kitüntetett I. világháborús hős rohamcsapat-parancsnok, vitéz Bertalan Árpád személyisége volt az a szükséges hajtó- és kötőerő, ami egyben tartotta a fiatal, sok nehézséggel küzdő alakulatot. Már dr. Csongor Győző is így emlékezett az első találkozásra a legendás katonával:

„Ez a derék hadfi sok újitásáról volt nevezetes. Most is felszerelte magát különböző védelmi fegyverrel, köztük revolverrel, kézigránátokkal, a hátán karabéllyal, abbéli rettenthetetlen meggyőződésétől vezetve, hogy az ejtőernyős akár a levegőben, akár a földre érkezéskor védelmezheti magát"!16

A Bertalan százados felhívására jelentkező tisztek, név szerint Vértes Béla, Mátray Károly, Lédeczy László, Pataky Géza, Majthényi Imre, Kiss Zoltán és Szokolay Tamás hadnagyok, ${ }^{17}$ a Magyar Királyi Honvédség egész állományából, az ország minden szegletéből önként jelentkező, fizikailag a repülés és ejtőernyőzés követelményeinek megfelelő katonák voltak, köztük több sportolóval. A keret indulására jellemző az idősebb csapattisztek ellenséges reakciója, amit Szokolay hadnagy így ír le:

„Szinte kötelességüknek érezték, hogy a fiatal tiszteket lebeszéljék erröl a nyaktörő vállalkozásról, amit öngyilkosságnak tartottak."18

Ez a szemlélet végigkísérte az ejtőernyős csapatok indulását, és e sorok szerzőjének véleménye szerint nagyban hozzájárult ahhoz, hogy az ejtőernyős alakulat tagjaiban nagyobb fokú öntudat és bizonyítási vágy is kialakult.

A kísérleti keret első ejtőernyős ugrására, szoktató repülések után, olasz eredetű hárommotoros Caproni Ca. 101es bombázó repülőgépekből, a veterán kiképző Czékus Ferenc repülő százados instrukciói alapján, 1938. szeptember 2-án került sor. A távol lévő Bertalan százados ekkor a kísérleti keret legénységi állományú tagjainak toborzását végezte. ${ }^{19}$

A Szombathelyen maradt leendő ejtőernyős tisztek bekötött ugrására 1000 méter magasságban, két hullámban került sor német Heinecke és olasz Salvator ejtőernyőkkel. $A z$ első négy ugró közül ketten földet éréskor lábukat tör-

4. ábra. Ejtőernyős kötelékugrás

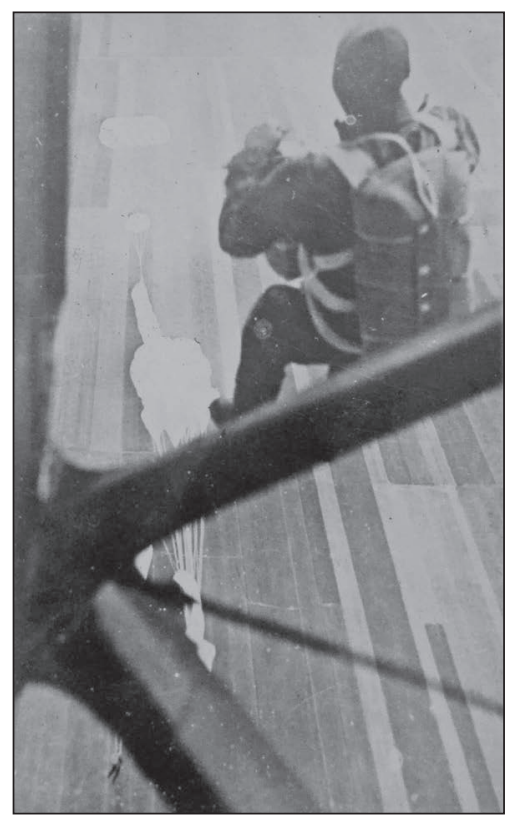


ték, míg egyikük egyszerűen nem akart földet érni. A mai ejtőernyősök által már jól ismert felfelé áramló meleg légáramlat, az úgynevezett „termik” felszálló oszlopa a háternyő nyitása után lendítette felfelé az ugrót, aki csak hoszszas lebegést követően jutott ki a furcsa fogságból. A második csoport az elkövetett hibákból tanulva, gond nélkül hajtotta végre az ugrást. ${ }^{20}$ Ezzel megszületett a magyar fegyveres erők első ejtőernyős alakulata, amelynek kerete 1938. október 3-án elérte a 27 fős létszámot. ${ }^{21}$

Az 1939-es év számos nagy változást tartogatott az ejtőernyősök számára. Nagy előrelépés volt a keret századdá alakulása, és 1939. október 1-jétől a légierő kötelékébe történt felvétele. ${ }^{22}$ Az ejtőernyős alakulat anyagi-technikai ellátását a soproni 4/III. gyalogzászlóalj kapta feladatul. ${ }^{23}$ Emellett az alakulat 1939. október 1-én Szombathelyről Pápára diszlokált, amiben nagy szerepe volt a frissen megürült pápai huszárlaktanya és a pápai repülőtér elhelyezkedésének is. ${ }^{24}$

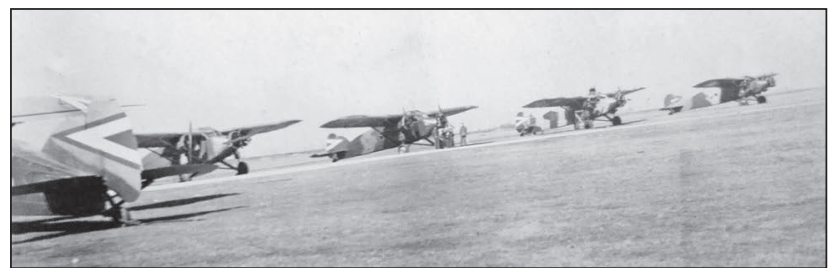

\section{5. ábra. Caproni Ca.101-es repülögépek Pápán}

A fentieken túl szükségessé vált egy új, ejtőernyős ugróruházat kialakítása is. Így jött létre a repülőhajózó nyári kezeslábast alapul vevő, de attól több elemében eltérő 1939M egybeszabott ugróruha, amelyet dr. Reszegi Zsolt cikke a Haditechnika folyóirat 2017/1-2. számaiban részletesen bemutatott. ${ }^{25}$

A vitorlavászonból készült kezeslábas hiteles másolata jelen sorok írójának rendelkezésére áll, így személyes tapasztalat alapján elmondható, hogy bár repülőgépben mozogva praktikus lehet, de földi tevékenység, különösen

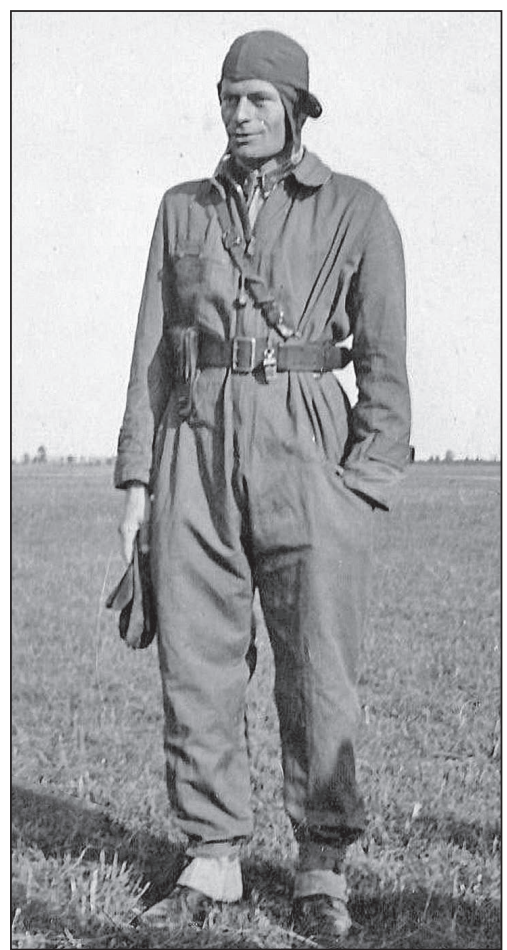

a harctevékenység során előforduló fokozott fizikai igénybevétel során a kezeslábas jellegű ruházat kényelmetlennek bizonyul. Különösen igaz ez a füleket fedő, így a hallást tompító vászon fejvédőre, amelyet korabeli fényképek szerint ugrás előtt, vagy a földön inkább kikapcsolt álszíjjal, vagy a fejtetőn rögzítve viseltek az ejtőernyősök.

$A z$ új ugróruha mellett új ejtőernyő, a Hehs Ákos mérnök százados által

\section{6. ábra. Ejtőernyős zászlós 1939M egybeszabott ugróruhában és fejvédővel}

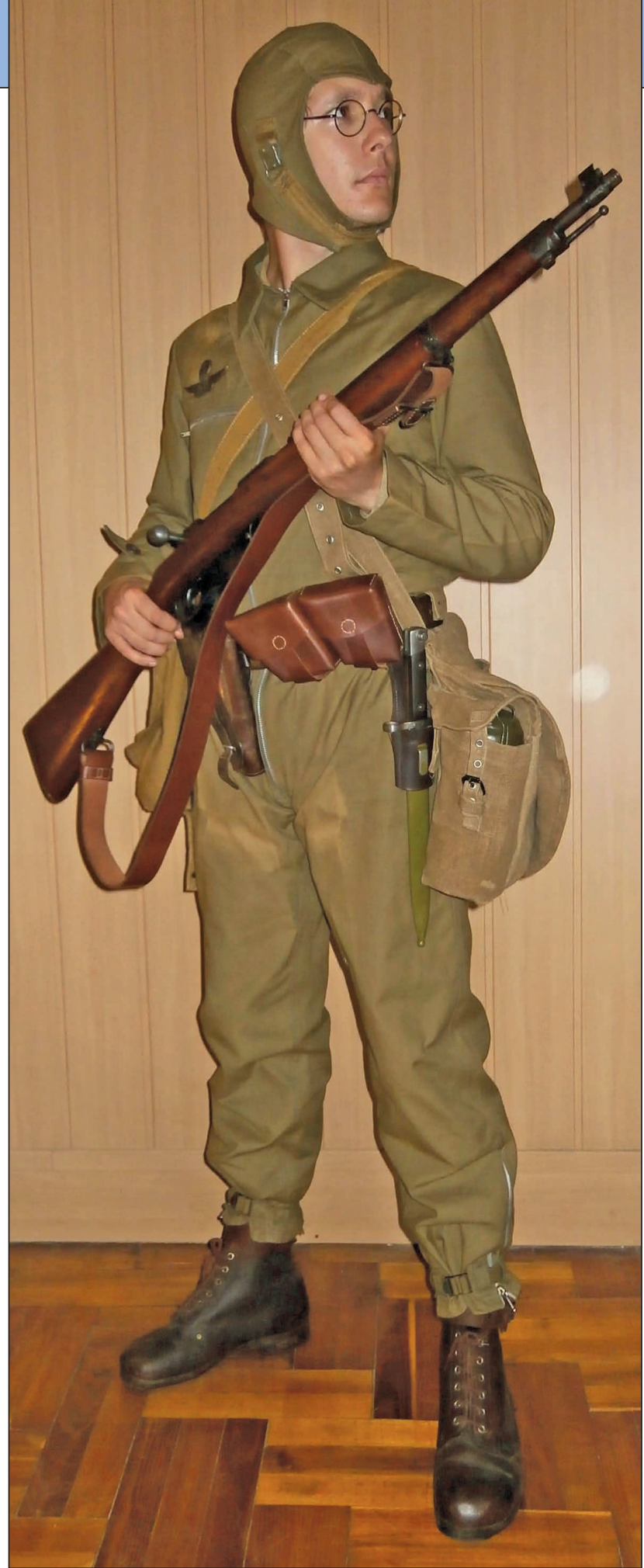

7. ábra. II. világháborús ejtőernyős hagyományőrző teljes felszerelésben

tervezett 39M H Gy. kettős gyakorló ejtőernyőt is rendszeresítették az addig használt olasz (Salvator), német (Heinecke és Schröder), valamint az angol-amerikai (Irvin) ejtőernyők helyett. ${ }^{26} \mathrm{Az}$ új, magyar tervezésű és hazai gyártású ejtőernyő bekötött ugrások és kézi kioldású nyitás, úgynevezett zuhanóugrás végrehajtására is alkalmas volt, így optimális eszköze volt a tömeges ledobásra és kis létszámú diverzáns feladatokra egyaránt felkészített ejtőernyős alakulatnak. ${ }^{27} \mathrm{Az}$ ejtőernyő-rendszer egy háternyőből és egy, az ugró hasára felszerelt mentőernyőből állt, így üzembiztonság tekintetében megelőzte az angol, vagy német ejtőernyősök hasonló eszközeit, hiszen a fenti or- 


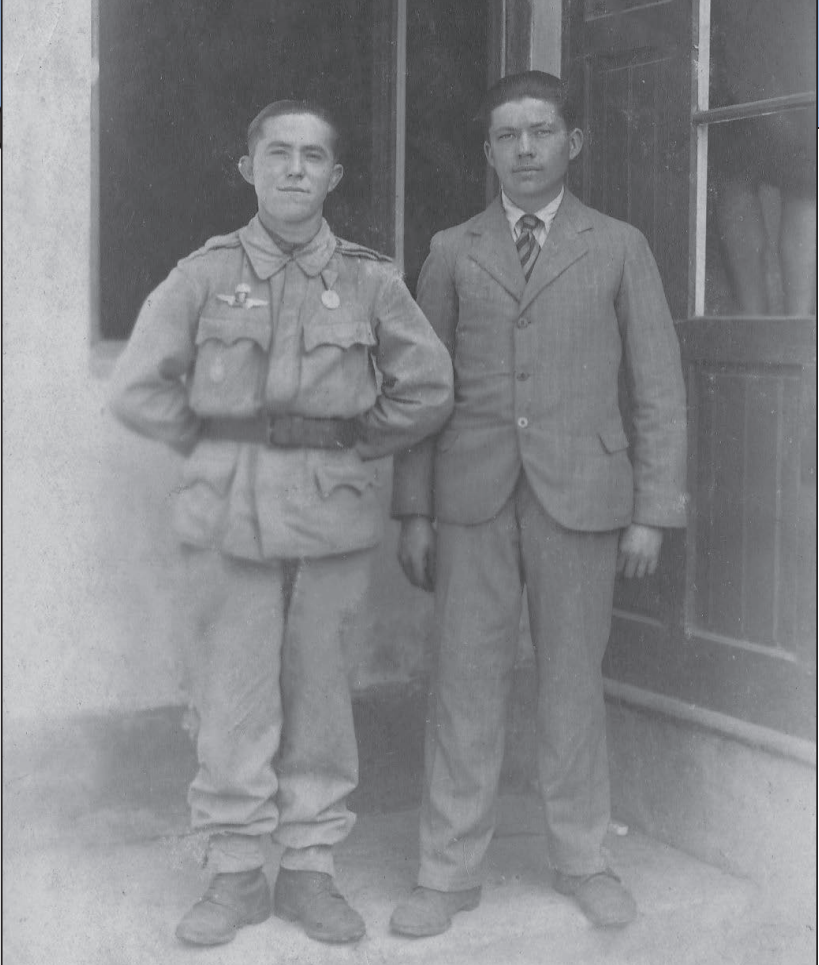

12. ábra. Büszke ejtőernyős nyári gyakorlóruhában, mellén ejtőernyős csapatjelvénnyel és az erdélyi bevonulás emlékérméve

várni kellett. Bertalan őrnagy a társadalom elismerő támogatása ellenére még mindig nehéz helyzetben volt, amikor alakulata erényeit kellett bizonyítania a Honvédelmi Minisztérium felé, hiszen több sikeres bemutatón, az erdélyi bevonuláson és emberei kiemelkedő morálján kívül, más kézzel fogható eredményt nem tudott felmutatni, míg a német ejtőernyős alakulatok 1940-ben már kivették részüket a dániai, norvégiai, hollandiai és belgiumi harcokból, bizonyítva az ejtőernyős koncepció létjogosultságát és a saját felkészültségüket is. ${ }^{38}$

A magyar katonai ejtőernyősök 1941. április 12-én estek át a tűzkeresztségen, amikor a délvidéki támadó hadművelet keretében egy körülbelül 100 fős harccsoporterőben vetették be őket. Az ejtőernyősök feladata a Ferenc-csatorna hídjának elfoglalása volt Szenttamásnál, mielőtt a szerb erők felrobbantanák azt. ${ }^{39}$ Érdemes megjegyezni, hogy a délvidéki támadó hadművelet előzetes terveiben nem szerepelt ejtőernyős bevetés, azt Bertalan őrnagy közbenjárására, pótlólag csatolták hozzá, valószínűleg a fentebb már említett bizonyítási kényszer miatt. ${ }^{40}$

$A z$ ejtőernyős harccsoport parancsnoka Majthényi Imre főhadnagy volt, akit valós haditapasztalatokkal a zászlóaljból egyedüliként rendelkező tisztként, Bertalan őrnagy is elkísért az E-101 oldalszámú SM.75-ös repülőgép fedélzetén. ${ }^{41}$

A négy repülőgépből álló kötelék a kora tavaszi esőzések miatt felázott pápai repülőtérről felszállni nem tudott, így a szállítórepülő-század parancsnokának, Kelemen Károly repülő századosnak utasítására a bevetést a veszprémi, betonozott repülőtérről indították meg, ahová a repülőgépek üresen, a harccsoport tagjai és a felszerelések pedig teherautókon települtek át. ${ }^{42}$

13. ábra. Ejtőernyősök beszállása SM.75-ös repülőgépekbe

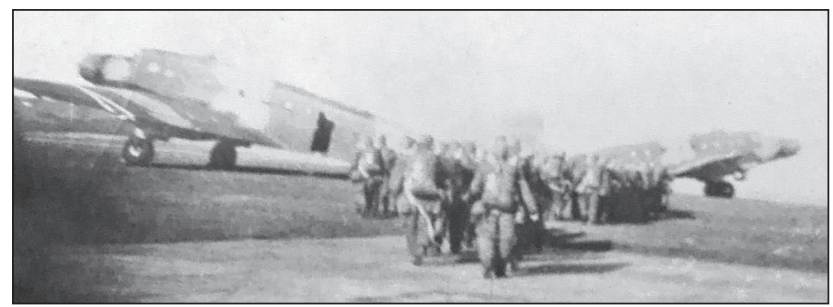

A bevetésre induló repülőgépekbe az ejtőernyősök 1941. április 12-én 16:45-kor szálltak be. Az elsőként felszálló E-101 oldalszámú parancsnoki repülőgép 17:00-kor emelkedett el a veszprémi betonról, majd átbillenve, jobb szárnyával a föld felé, zuhanni kezdett. Ezekre a pillanatokra így emlékezik vissza a fedélzeten lévő Szokolay Tamás főhadnagy:

„A zuhanás pillanatában önkéntelenül körbepillantottam a gépben. Minden ember a helyén ült Bertalan az ajtó kinyitásával foglalatoskodott. Majthényi, aki közvetlenül előttem állt, kinyitotta a jobboldali ajtót és ugrani akart. (...) Visszarántottam, erősen megkapaszkodtam a szemben lévő merevítöben és már a földön is voltunk. $A$ gép, erösen jobbra dült helyzetéböl visszatért megközelítőleg vízszintes helyzetbe, de még így is, jobb szárnyával ért elöször földet. Majthényi kilépett a félig nyitott ajtón. Ebben a pillanatban hallottam a kiáltást: „Eg a gép!” A következő másodpercben Sacelláry zászlós és egy ejtőernyős katona kiléptek a gépböl. Ekkor egy tüzcsóva vágott végig a gépen, melyet szerencsére nem szembe, hanem csak félbalról kaptam és így a repülősapka megvédte arcomat és csak kisebb sérüléseket okozott. Ekkor én is - kissé szédelegve, de - kiugrottam az égő gépből. Utánam ezen az ajtón nem jött már ki senki sem; ezt biztosan tudom, mert hátrálva távoztam a géptől, ahogy a hőség fokozódott."43

A felszállást a repülőtér parancsnoksága leállította, a lángokban álló roncsból kijutott sebesültek ellátását azonnal megkezdték, ám a veszprémi repülőtéren nem állt rendelkezésre megfelelő tűzoltó-felszerelés, ráadásul az ejtőernyősök felszerelésébe tartozó lőszer és robbanószer folyamatos robbanásai is lehetetlenné tették a mentést. ${ }^{44}$ A repülőgépből összesen nyolc fő jutott ki élve, négyen a gép vászonborítását áttörve, vagy rohamkéssel kivágva, négyen pedig az ajtókon át, illetve a géptörzsön lecsúszva. A repülőgépben keletkezett tűzben halt hősi halált Kelemen Károly repülő százados, az ejtőernyős szálítószázad parancsnoka, vitéz Bertalan Árpád ejtőernyős őrnagy, az ejtőernyős zászlóalj parancsnoka és még 18 repülőhajózó és ejtőernyős katona. ${ }^{45}$

A harccsoport parancsnokságát Kiss Zoltán ejtőernyős főhadnagy vette át, aki négy géppel és körülbelül 80 katonával 19:00 után indulhatott útnak. ${ }^{46} \mathrm{~A}$ harccsoport sötétben, 1941. április 12-én 19:00 után hajtott végre kötelékugrást, 15-20 kilométerre a céltól, Szabadka-Dél (Napfény) területén földet érve. ${ }^{47} \mathrm{Az}$ ejtőernyős harccsoport az ellenséggel vívott rövid tűzharc után vette fel a kapcsolatot az előre törő Sándor-csoport előőrsével. ${ }^{48}$ Sándor alezredes az ejtőernyősöket gépkocsikra ültette és másnap, április 13-án reggel együtt érték el Szenttamást. ${ }^{49} \mathrm{Az}$ ejtőernyősök a múút jobb oldalán mozogtak előre a műszaki zárakkal megerősített és betonbunkerekkel védett, robbantáshoz előkészített hídig, ${ }^{50}$ majd Kiss Zoltán ejtőernyős főhadnagy vezetésével a Ferenc-csatornán átkelve elfoglalták a

14. ábra. Ejtőernyősök a Sándor-csoport járművein, a Délvidéken

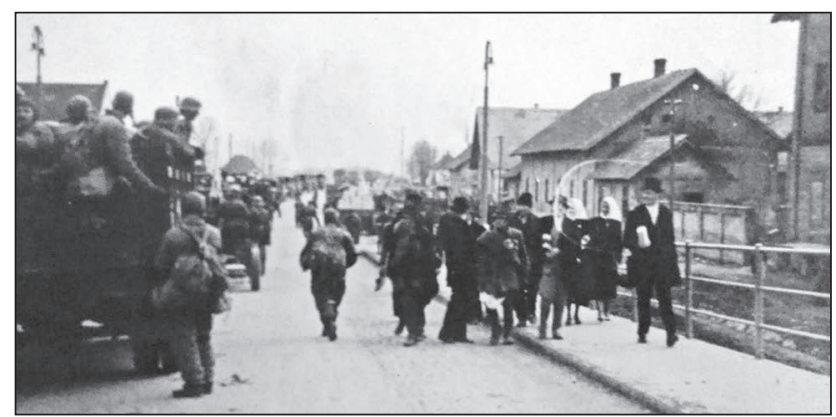




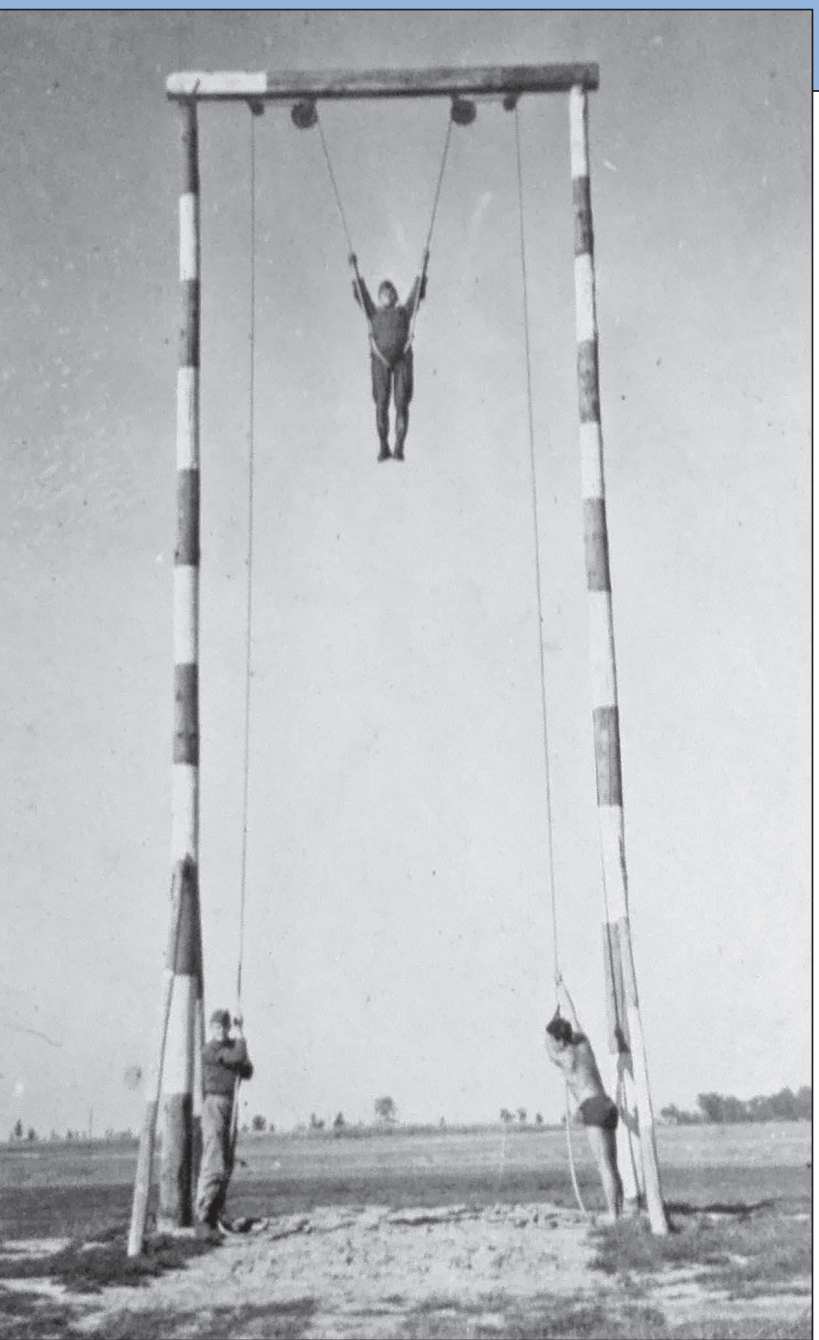

15. ábra. Ejtőernyős katona kiképzése a „bitón”, azaz földi ejtőernyős-gyakoroltató berendezésen

túlparti hídfőt. ${ }^{51}$ Ezt követően az ejtőernyős harccsoport tagjai a Sándor-csoport alárendeltségében harcoltak, amely egészen április 15-ig tartózkodott a hadműveleti területen. ${ }^{52}$

Az ejtőernyősök Újvidék északi részének biztosítását követően részt vettek a város és környékének megtisztításában, majd autóbuszokkal Pápára szállították őket. ${ }^{53} \mathrm{Az}$ alakulat hősi halált halt parancsnoka emlékére 1941. május 17-én vette fel a Magyar Királyi vitéz Bertalan Árpád 1. Honvéd Ejtőernyős Zászlóalj nevet, Pápa városa pedig a repülőtérre vezető út átnevezésével tiszteleg emléke előtt. ${ }^{54}$

A szerencsétlenség vizsgálata során derült ki, hogy a pápai repülőtéren szabad ég alatt tárolt „Savoiák” vászonborítása alá befolyt esővíz és hólé korrodálta magassági kiegyenlítő „trimm” rendszerét. ${ }^{55}$ Ez a körülmény nehezítette meg a repülőgép emelkedését a felszállás során, hiszen azt pusztán a három motor ereje hajtotta ekkor. A jelenség kívülről akár túlterheléshez hasonló is lehetett, ám ezt a lehetőséget kizárja az a körülmény, hogy Kelemen százados, a típus jó ismerője határozta meg a repülőgépek egyenkénti terhelését, amit az ejtőernyős állomány egyik tagja sem változtathatott meg. ${ }^{56}$

Bertalan őrnagy utódjának Labancz Gyula vezérkari őrnagyot nevezték ki, aki rövid ideig korábban szolgált az ejtőernyős alakulatnál. Róla Szokolay Tamás főhadnagy így írt:

„Nem nézte jó szemmel Bertalanhoz való ragaszkodásunkat, még az emlékére is féltékeny volt. Lekicsinylö megjegyzéseket tett elödjére, ami ellen tisztek és legénység egyaránt felzúdult, hiszen Bertalant úgy szerettük, mint az apánkat. Véget akart vetni a Bertalan féle „liberális” mód-

szereknek - sokszor szakszerütlen és veszélyes - ellenintézkedések bevetésével." ${ }^{157}$

A pápai ejtőernyős alakulat ezt követően nem vett részt nagyobb szabású ejtőernyős bevetésben. 1941. július 6-án az ejtőernyős szállító század és 10 fő ejtőernyős utasítást kapott a Kolomeától délre előretörésben lévő magyar 1. hegyidandár légi úton történő utánpótlására, amit a kijelölt állomány, kisebb nehézségek árán végre is hajtott. ${ }^{58} \mathrm{Ez}$ a bevetés megmutatta a fegyvernemek közti együttműködés fontosságát, mivel az ejtőernyősök a saját vonalakat jelző tüzeket és füstjelzéseket nem látták, majd kiugrás után baráti tűzbe kerültek. Továbbá földet érés után a saját csapatoktól az ellátmányt tartalmazó teherkonténerek összegyűjtésére, szállítására sem kaptak segítséget. ${ }^{59}$

1942-1943 során a pápai ejtőernyős alakulat életében jelentős eseménynek számított az 1942. május 25-i csapatzászló-avatás, amelynek házigazdája a Labancz őrnagy leváltását követően az ejtőernyős zászlóalj élére került vitéz Szügyi Zoltán ejtőernyős alezredes volt. ${ }^{60} \mathrm{Az}$ ejtőernyős alakulat tisztjei és altisztjei lehetőséget kaptak arra is, hogy 3-3 hónapos turnusokban „haditapasztalatok megszerzése céljából" a keleti fronton harcoló alakulatoknál rendfokozatuknak megfelelő beosztásban szolgálhassanak. ${ }^{61} \mathrm{~A}$ fronton az ejtőernyősöket mindenhol pozitívan fogadták, szakmai felkészültségük, személyes példamutatásuk okán. ${ }^{62}$

Fontos megemlíteni az ejtőernyős alakulat légi szállító képességének utolsó megjelenését, az 1944. szeptember 26-27-én, Nagyváradon végrehajtott deszantolást, amelynek során új, FIAT G. 12-es szállító repülőgépeken egy

\section{6. ábra. A II. ejtőernyős zászlóalj katonái 1945 elején, Pápán}

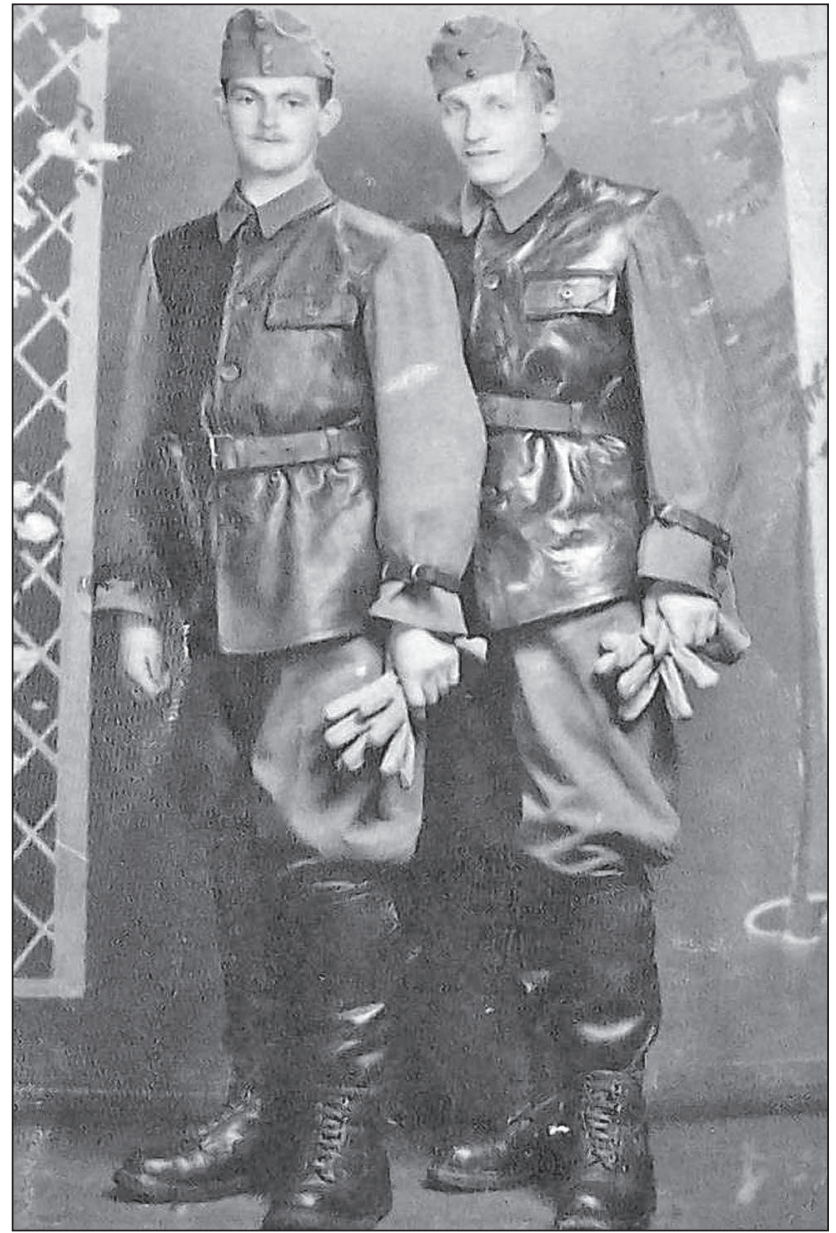


század erőben, leszálló deszant módszerrel tettek ki ejtőernyős katonákat az 1944. augusztus 23-ai román átállás miatt kulcsfontosságúvá vált nagyváradi repülőtéren. Az állományt a Pápán ekkor szerveződő II. ejtőernyős zászlóalj magvát jelentő veteránok, kiképzők adták, parancsnokuk pedig a délvidéki harci ugrás veteránja, Kiss Zoltán ejtőernyős százados volt. ${ }^{63} \mathrm{~A}$ század erejü, 154 fős kötelék a nagyváradi kirakodást követően Váradlesre menetelt, ahol október 3-ig, a megújuló szovjet - román támadásokban az ejtőernyősök összesen 71 katonát vesztettek halottakban és sebesültekben. ${ }^{64}$

A nagyváradi bevetést követően az ejtőernyősök két zászlóalj erőben, a Szent László hadosztály keretében elit könnyűgyalogságként, „tűzoltó-alakulatként” harcoltak, ugrás nélkül. Ahogy Ábel Béla Gusztáv, a II. ejtőernyős zászlóalj nehézfegyver-századának aknavetőse emlékezett a háború utolsó éveire:

„Az ejtőernyős alakulat a körülményekhez képest még mindig harcképes, elit alakulatnak számított. Ezért azután az egyik helyröl a másikra rendeltek oda, ahol nagyobb volt a baj. Úgy látszott, volt ilyen hely böven, mert folyton mentünk. Ha csak egy-két napra tudtuk is megállitani az oroszokat, az már sikernek számított."65

Összességében elmondható, hogy a II. világháború magyar ejtőernyős csapatneme a maga lehetőségei között formabontó, új felhasználási módjait alakította ki az ejtőernyős kirakásnak egy olyan korszakban, amikor még a repülés is újdonságnak számított. Az 1938 és 1939 között kidolgozott elméleti és technikai újítások azonban az alakulat átgondolatlan felhasználása, valamint a felsőbb katonai vezetés rugalmatlansága okán nem érvényesülhettek a gyakorlatban. Az alakulat ennek ellenére, kiképzésének és szellemének köszönhetően a méreténél jóval nagyobb mértékű ellenállást fejtett ki a harcok során bekerítésben, vagy épp súlyos veszteségek elszenvedése után is, egyaránt kivívva ezzel a szövetségesek és az ellenség megbecsülését.

\section{JEGYZETEK}

1 Dr. Boda József, dr. Ruszin Romulusz: Levegőből harcba - A magyar katonai ejtőernyőzés története és változó feladatrendszere (Zrínyi Kiadó Budapest, 2012.) pp. 17-18. (a továbbiakban: RUSZIN-BODA).

2 RUSZIN-BODA: p. 18

3 http://nagyhaboru.blog.hu/2018/01/16/_n_vagyok_az_elso_ki_ onkent_ugrott_le [letöltés ideje: 2018. 06. 05.]

4 RUSZIN-BODA: pp. 17-18.

5 V.ö.: vitéz Szentnémedy Ferenc: A Függőleges Átkarolás Kérdéséhez (in.: Magyar Katonai Szemle 1937. 2. sz. p. 7.)

6 1934-ben 900, 1935-ben pedig már 1200 ejtőernyős ledobásával kiegészített hadgyakorlatokra került sor a Belorusz Katonai Körzet, illetve a Kievi Katonai Körzet hadgyakorlatain, amelyekre a világsajtó és a katonai diplomácia képviselői is meghívást kaptak; (Turcsány Károly, Hegedűs Ernő: A Légideszant I. - elméletek, eljárások és a légi gépesítés a kezdetektől 1945-ig.) Puedlo kiadó, Nagykovácsi, 2008. p. 124. a továbbiakban: TURCSÁNYI-HEGEDÜS 2008).

7 Reszegi Zsolt: Légi huszárok - Az ejtőernyős csapatnem kialakulása és harcai 1938 és 1945 között. (A pápai levéltár kiadványai, Budapest Pápa 2013. p. 12. A továbbiakban: RESZEGI.)

8 RUSZIN-BODA: p. 20

9 RESZEGI: p. 132

10 Dr. Csongor Győző: Testnevelési Szaktanfolyam; (in.: Magyar Szárnyak 1997. XXV. évf. 25. szám pp. 182-183. a továbbiakban: CSONGOR

11 RESZEGI: p. 131

12 RESZEGI: p. 129.

13 CSONGOR: p. $182-183$

14 RESZEGI: p. 132.

15 Huszár János: Honvéd Ejtőernyősök Pápán 1939-1945. (Jókai Kör Pápa, 1993. p.10. a továbbiakban: HUSZÁR) .

16 CSONGOR: p. 183

17 Szokolay Tamás: A magyar ejtőernyősök lovagkora 1938-1941.; (in Kanadai Magyar Szárnyak 1985. p. 39. a továbbiakban: SZOKOLAY)

18 SZOKOLAY: u.o.

19 SZOKOLAY: pp. 40-41.

20 SZOKOLAY: p. 41.

21 SZOKOLAY: p. 43

22 RESZEGI: p. 37.

23 u. o

24 HUSZÁR: p. 31

25 v. ö.: Dr. Reszegi Zsolt: Ejtőernyős ugróruházat I. rész; (in.: Haditechnika LI. évf. 2017/1. pp. 62-66) és Dr. Reszegi Zsolt: Ejtőernyős ugróruházat II. rész; (in.: Haditechnika LI. évf. 2017/2. pp. 60-65.) 26 RESZEGI: p. 252

27 Szokolay Tamás: Ejtőernyőugrás, a jövő legkatonásabb sportja; (in.: Magyar Katonai Szemle IX. évfolyam 1939/9. szám pp. 133-134.).

28 TURCSÁNYI-HEGEDÜS 2008: p. 36. és p. 94

29 Makray Ferenc: Az ejtőernyős csapatok magyar szemmel nézve (in.: Magyar Katonai Szemle IX. évfolyam 1939/9. szám p. 145.; (a továbbiakban: MAKRAY).

30 HALO: (High Altitude Low Opening - nagy magasságból, alacsony nyitási magassággal végrehajtott ejtőernyős ugrás). A magyar katonai szakirodalom a technológia elterjedését az Amerikai Egyesült Államok különleges műveleti erőihez köti, ám az 1939 szeptemberi

Makray-cikk alapján látható, hogy legalább az elméleti alapok jóval korábban megjelentek Magyarországon is. v. ö.: RUSZIN-BODA pp. 152-153.

31 MAKRAY p. 145

32 MAKRAY: p. 145.

33 RESZEGI: p. 253.

34 SZOKOLAY: p. 84.

35 HUSZÁR: p. 49.

36 HUSZÁR: p. 53.

37 Ábel Béla Gusztáv: Göröngyös utakon! Visszaemlékezések (kézirat a szerző tulajdonában) p. 36.; (a továbbiakban: ÁBEL).

38 TURCSÁNYI - HEGEDÜS 2008: pp. 25-27. illetve Hegedűs Ernő

- Turcsányi Károly: A magyar légideszant-csapatok alkalmazásának haditechnikai eszközeinek és szervezetének fejlődése (1933-1945);

(in: II. rész Katonai Logisztika, 2006. évi 4. sz. pp. 159.)

39 SZOKOLAY: p. 57.

40 HUSZÁR: p. 69.

41 SZOKOLAY: p. 57.

42 HUSZÁR pp. 69-70.

43 SZOKOLAY: p. 58.

$44 \mathrm{u}$. $\mathrm{O}$.

45 RESZEGI: p. 178

46 SZOKOLAY: p. 58.

47 Horváth Csaba - Lengyel Ferenc: A Délvidéki Hadművelet 1941. április (Puedlo kiadó Debrecen), p. 85.; (a továbbiakban: HORVÁTHLENGYEL).

48 HUSZÁR: p. 74

49 HORVÁTH-LENGYEL: p. 89.

50 HORVÁTH-LENGYEL: p. 88.

51 HUSZÁR: p. 105

52 HORVÁTH-LENGYEL: p. 105.

53 HUSZÁR: p. 75.

54 HUSZÁR: p. 77

55 RESZEGI: p. 178.

56 SZOKOLAY: p. 59-60

57 SZOKOLAY: p. 56.

58 HUSZÁR: pp. 78-79.

59 HUSZÁR: p. 79.

60 HUSZÁR: p. 85

61 HUSZÁR: p. 91.

62 Lásd Legeza János vezérőrnagynak, a Donnál harcoló VII. hadtest parancsnokának 1943. január 8-án kelt naplóbejegyzését: „(..) Látogatás a 43. gyalogezrednél. Vitéz Szügyi ezredes csupa bizakodás, tetterő és aktivitás. Amíg ez az ember a Marki-völgyben van, nyugodt lehetek (...)." in.: Bajor Péter - Szabó Péter: Requiem egy tábornokért - Legeza János élete, doni naplója és más feljegyzései, Mikes kiadó Budapest, 2008. p. 146.

63 HUSZÁR: p. 118.

64 RESZEGI: pp. 190-193.

65 ÁBEL: p. 101-102. 